See discussions, stats, and author profiles for this publication at: https://www.researchgate.net/publication/335339257

\title{
Chemical and Mechanical Properties of Reinforcing Steel Bars from Local Steel Plants
}

Article in Journal of Failure Analysis and Prevention · August 2019

Dol: 10.1007/511668-019-00695-x

CITATIONS

5 authors, including:

Jamiu Odusote

University of Ilorin

61 PUBLICATIONS 159 CITATIONS

SEE PROFILE

Peter Ikubann

Landmark University

36 PUBLICATIONS 35 CITATIONS

SEE PROFILE

Some of the authors of this publication are also working on these related projects:

Honey extractor View project

Green metallurgical process/Improvement of Lean-grade coal/non-coking coal View project
Adekunle Akanni Adeleke

University of Ilorin

28 PUBLICATIONS 51 CITATIONS

SEE PROFILE 


\title{
Chemical and Mechanical Properties of Reinforcing Steel Bars from Local Steel Plants
}

\author{
Jamiu Kolawole Odusote - Wasiu Shittu • Adekunle Akanni Adeleke • \\ Peter Pelumi Ikubanni $\cdot$ Olumide Adeyemo
}

Submitted: 13 February 2019/in revised form: 6 June 2019

(C) ASM International 2019

\begin{abstract}
Steel bars are important engineering materials for structural application. In Nigeria, due to incessant building collapse occurrences, it is important to further investigate some of the mechanical and chemical properties of reinforcing steel bars produced from scrap metals in order to ascertain their compliance with the required standard. Three diameters $(10,12$ and $16 \mathrm{~mm})$ of the reinforcing steel bars were chosen from each of the eight steel plants $(\mathrm{A}-\mathrm{H})$. Chemical composition analyses and mechanical tests (yield strength, ultimate tensile strength and percentage elongation) were performed using optical emission spectrometer and Instron Satec Series 600DX universal testing machine, respectively. Hardness values of the samples were obtained by conversion of tensile strength based on existing correlation. The results showed that
\end{abstract}

J. K. Odusote · W. Shittu

Department of Materials and Metallurgical Engineering,

University of Ilorin, Ilorin, Kwara State, Nigeria

J. K. Odusote

e-mail: odusote.jk@unilorin.edu.ng

W. Shittu

e-mail: ruud750.sw@gmail.com

A. A. Adeleke ( $\square)$

Department of Mechanical Engineering, University of Ilorin,

Ilorin, Kwara State, Nigeria

e-mail: adeleke.kunle@ymail.com

P. P. Ikubanni

Department of Mechanical Engineering, Landmark University,

Omu-Aran, Kwara State, Nigeria

e-mail: ikubanni.peter@lmu.edu.ng

O. Adeyemo

Midwal Engineering Services Limited, 5B Elengaza Mall, Ikota, Lekki, Lagos, Nigeria carbon contents, hardness values, yield and ultimate tensile strengths of some of the steel bars were found to be higher than the BS4449, NIS and ASTM A706 standards. The steel bar samples were also found to possess good ductility with samples from steel plants $\mathrm{C}$ and $\mathrm{D}$. By observation, all the $12 \mathrm{~mm}$ steel bars from steel plants $\mathrm{A}$ to $\mathrm{H}$ met the required ASTM and BS4449 standards except samples from plant G. This study revealed that most of the investigated reinforcing steel bars have reasonable yield strength, ultimate tensile strength, ductility and hardness properties when compared with the relevant local and international standards. Therefore, they are suitable for structural applications where strength and ductility will be of paramount interest.

Keywords Reinforcing steel bars .

Universal tensile machine - Chemical composition .

Mechanical properties $\cdot$ Structural applications

\section{Introduction}

Steel is regarded as one of the most widely used engineering materials in the world for structural purposes. In both developed and developing world, the steel industry is recognized as one of the most outstanding outlets of industrialization and economic growth [1]. Steel products find applications in building and construction, oil and gas, mining, telecommunication, automobile and many other industries [1]. Steel bars are largely used as reinforcement in concrete for structural support of buildings and other critical constructions $[2,3]$. This is due to its good bonding properties with concrete, its closeness in thermal coefficient of expansion with concrete, good weldability for site 
fabrication, among others [1, 4]. Reinforcing steel bar plays a significant role as construction materials, and thus, its properties must be ascertained before being used for structural support in order to reduce or eliminate the incidences of building and structure failures, which have become more rampant in Nigeria. These failures have usually resulted in loss of lives and properties, thereby making regular examination and characterization of steel bars used as reinforcement in concrete even more important. Currently, most of the reinforcing steel bars used in the construction industries in Nigeria are produced majorly from scraps. Several researchers [2, 5-10] have investigated causes of collapse of building in Nigeria, and some have worked on improving the mechanical properties of the reinforcing steel bars through heat treatment [11-13]. One of the major causes reported is that the structural properties of some of the reinforcing steel bars used in the actual constructions do not conform to relevant standards. In addition, it was revealed that qualified engineers are often not involved in the construction work [5].

In order to reduce or avert further loss of lives and properties associated with building collapses and structural failures, chemical composition analyses and mechanical properties of steel bars produced from scrap metals needed to be investigated. Therefore, in this study, the chemical and mechanical properties of reinforcing steel bars locally produced from scraps in Nigeria were investigated and compared with relevant local and international standards to ascertain their suitability for structural/construction purposes.

\section{Materials and Methods}

\section{Materials}

This research work was carried out in December 2016-July 2018 at Lagos and Ilorin Nigeria. Reinforcing steel bar samples locally produced from eight different steel plants were obtained from local steel markets in Lagos State, Nigeria. The bars were identified using Standard Organization of Nigeria (SON) identification and classification marks [14]. Three diameters $(10,12$ and $16 \mathrm{~mm})$ of the reinforcing steel bars were selected from each of the eight steel plants making the total number of samples used for the study to be twenty-four. The samples were each coded based on the steel plant $(\mathrm{A}, \mathrm{B}, \mathrm{C}-\mathrm{H})$ and samples diameter, $\mathrm{R}(10,12$ and $16 \mathrm{~mm})$. For example, samples from plant $\mathrm{A}$ were identified as $A_{1} R_{10}, A_{2} R_{12}$ and $A_{3} R_{16}$, where $A_{1}, A_{2}$, $A_{3}$ and $R_{10}, R_{12}, R_{16}$, represent the samples plant name and diameters, respectively. The subscript stands for the sample number and diameter of the sample, respectively. Similar approach was used for the identification of samples from other steel plants.

\section{Chemical Composition}

The chemical analysis was carried out using an optical emission spectrometer (LMF06, serial number 15007384). The 16-mm-diameter samples were prepared to fit into the 15-mm-diameter standard orifice of tungsten carbide disk to be mounted on the machine. However, the smaller diameters (10 and $12 \mathrm{~mm}$ samples) were incorporated into tungsten carbide disks equipped with $10-$ and $12-\mathrm{mm}$-diameter holes. The samples were ground and then polished to produce a smooth and flattened surface that was free of contaminants before being mounted on the machine. The test was performed in accordance with the specifications prescribed by NIS [15]. The average elemental percentage by weight (wt.\%) of the samples was displayed on a monitor connected to the equipment.

\section{Tensile Test}

Each test sample was neatly cut into three specimens of $300 \mathrm{~mm}$ each for the three samples sizes as shown in Fig. 1. The test was conducted using an Instron Satec Series 600DX universal tensile test machine with capacity of $600 \mathrm{kN}$. The specimen was mounted on the tensile test machine and subjected to continuous tensile loading at the rate of $10 \mathrm{~mm} / \mathrm{min}$ to the point of fracture. For better reliability of the results, the test was repeated three times and the mean values were recorded. The average percentage elongation was determined by fitting the two ends of the fractured samples together.

\section{Evaluation of Hardness}

The hardness properties of the test samples were obtained by linear interpolations from standard strength-hardness conversion table [16]. The reported data are the mean of the different tests and analyses.

\section{Results and Discussion}

\section{Elemental Composition}

The carbon (C), manganese (Mn), silicon ( $\mathrm{Si})$, chromium $(\mathrm{Cr})$ and other major residual elemental constituents of the samples from different steel plants are presented in Tables 1, 2 and 3, respectively. The carbon contents range from 0.20 to $0.35 \%$ for the $16 \mathrm{~mm}$ reinforcing steel bars from the various steel plants (Table 1). From Tables 1, 2 and 3, the $10 \mathrm{~mm}$ test samples have higher carbon content 
Fig. 1 Tensile test specimen
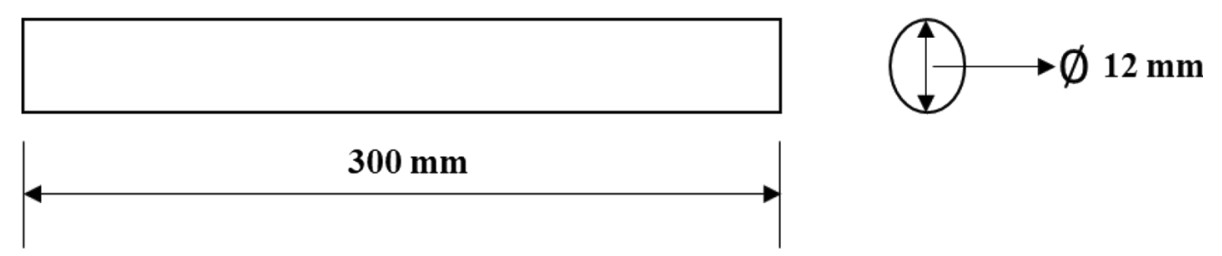

Table 1 Elemental composition of $16 \mathrm{~mm}$ reinforcing bar samples

\begin{tabular}{|c|c|c|c|c|c|c|c|c|}
\hline \multirow[b]{2}{*}{ Element (wt.\%) } & \multicolumn{8}{|c|}{ Samples } \\
\hline & $\mathrm{A}_{3} \mathrm{R}_{16}$ & $\mathrm{~B}_{3} \mathrm{R}_{16}$ & $\mathrm{C}_{3} \mathrm{R}_{16}$ & $\mathrm{D}_{3} \mathrm{R}_{16}$ & $\mathrm{E}_{3} \mathrm{R}_{16}$ & $\mathrm{~F}_{3} \mathrm{R}_{16}$ & $\mathrm{G}_{3} \mathrm{R}_{16}$ & $\mathrm{H}_{3} \mathrm{R}_{16}$ \\
\hline $\mathrm{C}$ & 0.200 & 0.220 & 0.190 & 0.200 & 0.230 & 0.340 & 0.210 & 0.350 \\
\hline $\mathrm{Si}$ & 0.240 & 0.100 & 0.120 & 0.340 & 0.150 & 0.180 & 0.140 & 0.240 \\
\hline $\mathrm{Mn}$ & 0.850 & 0.660 & 0.360 & 1.340 & 0.500 & 0.630 & 0.580 & 0.750 \\
\hline $\mathrm{P}$ & 0.030 & 0.020 & 0.030 & 0.020 & 0.010 & 0.030 & 0.020 & 0.030 \\
\hline S & 0.060 & 0.060 & 0.050 & 0.030 & 0.060 & 0.060 & 0.060 & 0.070 \\
\hline $\mathrm{Cr}$ & 0.200 & 0.320 & 0.160 & 0.070 & 0.110 & 0.190 & 0.270 & 0.260 \\
\hline Mo & 0.020 & 0.020 & 0.020 & 0.020 & 0.010 & 0.020 & 0.030 & 0.030 \\
\hline $\mathrm{Ni}$ & 0.130 & 0.210 & 0.150 & 0.060 & 0.090 & 0.160 & 0.140 & 0.140 \\
\hline $\mathrm{Al}$ & 0.001 & 0.002 & 0.002 & $<0.001$ & 0.004 & $<0.001$ & 0.002 & $<0.001$ \\
\hline Co & 0.010 & 0.020 & 0.010 & 0.010 & 0.008 & 0.010 & 0.010 & 0.009 \\
\hline $\mathrm{Cu}$ & 0.220 & 0.480 & 0.380 & 0.140 & 0.200 & 0.330 & 0.310 & 0.330 \\
\hline $\mathrm{Nb}$ & $<0.004$ & $<0.004$ & $<0.004$ & $<0.004$ & $<0.004$ & $<0.004$ & $<0.004$ & $<0.004$ \\
\hline $\mathrm{Ti}$ & $<0.001$ & $<0.001$ & $<0.001$ & $<0.001$ & $<0.001$ & $<0.001$ & $<0.001$ & $<0.001$ \\
\hline V & 0.007 & 0.009 & 0.005 & 0.0600 & 0.006 & 0.007 & 0.008 & 0.010 \\
\hline W & $<0.007$ & $<0.007$ & $<0.007$ & $<0.007$ & $<0.007$ & $<0.007$ & $<0.007$ & $<0.007$ \\
\hline $\mathrm{Pb}$ & $<0.002$ & $<0.002$ & $<0.002$ & $<0.002$ & $<0.002$ & $<0.002$ & $<0.002$ & $<0.002$ \\
\hline Sn & 0.020 & 0.030 & 0.030 & 0.008 & 0.020 & 0.020 & 0.020 & 0.0200 \\
\hline $\mathrm{Mg}$ & $<0.001$ & $<0.001$ & $<0.001$ & $<0.001$ & $<0.001$ & $<0.001$ & $<0.001$ & $<0.001$ \\
\hline As & 0.004 & 0.002 & 0.004 & 0.005 & 0.002 & 0.004 & 0.003 & 0.002 \\
\hline $\mathrm{Bi}$ & 0.002 & 0.003 & 0.003 & 0.003 & 0.003 & 0.002 & 0.003 & 0.003 \\
\hline $\mathrm{Ca}$ & 0.002 & 0.001 & 0.005 & 0.001 & 0.002 & 0.001 & 0.006 & 0.005 \\
\hline $\mathrm{Ce}$ & $<0.002$ & $<0.002$ & $<0.002$ & $<0.002$ & $<0.002$ & $<0.002$ & $<0.002$ & $<0.002$ \\
\hline $\mathrm{Sb}$ & 0.006 & 0.005 & 0.006 & 0.004 & 0.003 & 0.005 & 0.004 & 0.004 \\
\hline $\mathrm{Se}$ & 0.004 & 0.003 & 0.003 & 0.004 & 0.002 & 0.003 & 0.003 & 0.002 \\
\hline $\mathrm{Te}$ & 0.004 & 0.003 & 0.003 & 0.003 & 0.002 & 0.003 & 0.003 & 0.002 \\
\hline Ta & 0.040 & 0.050 & 0.050 & 0.060 & 0.050 & 0.050 & 0.050 & 0.040 \\
\hline B & 0.004 & 0.001 & 0.006 & 0.001 & 0.002 & 0.002 & 0.001 & 0.004 \\
\hline $\mathrm{Zn}$ & 0.007 & 0.002 & 0.040 & 0.004 & 0.010 & 0.010 & 0.003 & 0.002 \\
\hline $\mathrm{La}$ & $<0.001$ & $<0.001$ & $<0.001$ & $<0.001$ & $<0.001$ & $<0.001$ & $<0.001$ & $<0.001$ \\
\hline $\mathrm{Fe}$ & 97.900 & 97.800 & 98.400 & 97.600 & 98.500 & 97.900 & 98.100 & 97.700 \\
\hline
\end{tabular}

Major elements are given in bold

than 16 and $12 \mathrm{~mm}$ samples. The sulfur (S) and phosphorus (P) contents of $16 \mathrm{~mm}$ samples are in the range of $0.03-$ $0.07 \%$ and $0.01-0.03 \%$, respectively, as displayed in Table 1. Table 2 shows that the $\mathrm{S}$ and $\mathrm{P}$ content of the $12 \mathrm{~mm}$ samples are in the range of $0.01-0.08 \%$ and $0.01-$ $0.05 \%$, respectively. The $\mathrm{S}$ and $\mathrm{P}$ contents of $10 \mathrm{~mm}$ samples are in the range of $0.007-0.18 \%$ and $0.0006-$ $0.04 \%$, respectively (Table 3 ). The reinforcing bars from steel plant $\mathrm{D}$ have the highest $\mathrm{Mn}$ contents for $16 \mathrm{~mm}$
(1.34\%), $12 \mathrm{~mm}(1.52 \%)$ and $10 \mathrm{~mm}$ (1.51\%) samples. Tables 1, 2 and 3 show that there are thirty-one (31) elements all together in the reinforcing steel bars of various diameters.

Mechanical Testing

The yield and ultimate tensile strengths for the reinforcing steel bars of varying diameters from different steel plants 
Table 2 Elemental composition of $12 \mathrm{~mm}$ reinforcing bar samples

\begin{tabular}{|c|c|c|c|c|c|c|c|c|}
\hline \multirow[b]{2}{*}{ Element (wt.\%) } & \multicolumn{8}{|c|}{ Samples } \\
\hline & $\mathrm{A}_{2} \mathrm{R}_{16}$ & $\mathrm{~B}_{2} \mathrm{R}_{16}$ & $\mathrm{C}_{2} \mathrm{R}_{16}$ & $\mathrm{D}_{2} \mathrm{R}_{16}$ & $\mathrm{E}_{2} \mathrm{R}_{16}$ & $\mathrm{~F}_{2} \mathrm{R}_{16}$ & $\mathrm{G}_{2} \mathrm{R}_{16}$ & $\mathrm{H}_{2} \mathrm{R}_{16}$ \\
\hline $\mathrm{C}$ & 0.200 & 0.270 & 0.400 & 0.400 & 0.360 & 0.280 & 0.320 & 0.330 \\
\hline $\mathrm{Si}$ & 0.210 & 0.130 & 0.210 & 0.320 & 0.060 & 0.230 & 0.150 & 0.190 \\
\hline $\mathrm{Mn}$ & 0.830 & 0.620 & 0.590 & 1.520 & 0.480 & 0.560 & 0.560 & 0.660 \\
\hline $\mathrm{P}$ & 0.050 & $\mathbf{0 . 0 3 0}$ & 0.050 & 0.010 & $\mathbf{0 . 0 3 0}$ & 0.040 & 0.010 & 0.050 \\
\hline$S$ & 0.010 & 0.080 & 0.070 & 0.010 & 0.070 & 0.070 & 0.070 & 0.020 \\
\hline $\mathrm{Cr}$ & 0.250 & 0.230 & 0.150 & $\mathbf{0 . 0 3 0}$ & 0.160 & 0.110 & 0.220 & 0.330 \\
\hline Mo & 0.020 & 0.020 & 0.010 & 0.004 & 0.010 & 0.020 & 0.030 & 0.040 \\
\hline $\mathrm{Ni}$ & 0.160 & 0.150 & 0.120 & 0.005 & 0.100 & 0.110 & 0.260 & 0.170 \\
\hline $\mathrm{Al}$ & 0.010 & 0.004 & 0.010 & 0.040 & 0.005 & 0.002 & 0.008 & 0.010 \\
\hline Co & 0.010 & 0.020 & 0.010 & 0.006 & 0.009 & 0.010 & 0.010 & 0.010 \\
\hline $\mathrm{Cu}$ & 0.300 & 0.340 & 0.250 & 0.030 & 0.270 & 0.250 & 0.410 & 0.400 \\
\hline $\mathrm{Nb}$ & $<0.004$ & $<0.004$ & $<0.004$ & $<0.004$ & $<0.004$ & $<0.004$ & $<0.004$ & $<0.004$ \\
\hline $\mathrm{Ti}$ & $<0.001$ & $<0.001$ & $<0.001$ & $<0.001$ & $<0.001$ & $<0.001$ & $<0.001$ & $<0.001$ \\
\hline V & 0.005 & 0.006 & 0.004 & 0.060 & 0.005 & 0.005 & 0.009 & 0.007 \\
\hline W & $<0.070$ & $<0.007$ & $<0.007$ & $<0.007$ & $<0.007$ & $<0.007$ & $<0.007$ & $<0.007$ \\
\hline $\mathrm{Pb}$ & $<0.002$ & $<0.002$ & $<0.002$ & $<0.002$ & $<0.002$ & $<0.002$ & $<0.002$ & $<0.002$ \\
\hline Sn & 0.030 & 0.020 & 0.030 & 0.007 & 0.030 & 0.020 & 0.020 & 0.020 \\
\hline $\mathrm{Mg}$ & $<0.001$ & $<0.001$ & $<0.001$ & $<0.001$ & $<0.001$ & $<0.001$ & $<0.001$ & $<0.001$ \\
\hline As & 0.005 & 0.003 & 0.006 & 0.005 & 0.004 & 0.005 & 0.003 & 0.007 \\
\hline $\mathrm{Bi}$ & $<0.002$ & $<0.002$ & $<0.002$ & $<0.002$ & $<0.002$ & $<0.002$ & $<0.002$ & $<0.002$ \\
\hline $\mathrm{Ca}$ & 0.007 & 0.002 & 0.003 & 0.008 & 0.003 & 0.003 & 0.005 & 0.010 \\
\hline $\mathrm{Ce}$ & $<0.002$ & $<0.002$ & $<0.002$ & $<0.002$ & $<0.002$ & $<0.002$ & $<0.002$ & $<0.002$ \\
\hline $\mathrm{Sb}$ & 0.007 & 0.006 & 0.010 & 0.003 & 0.008 & 0.006 & 0.004 & 0.008 \\
\hline $\mathrm{Se}$ & 0.006 & 0.004 & 0.008 & 0.004 & 0.007 & 0.004 & 0.004 & 0.006 \\
\hline $\mathrm{Te}$ & 0.003 & 0.040 & 0.003 & 0.003 & 0.003 & 0.003 & 0.003 & 0.004 \\
\hline Ta & $<0.020$ & 0.030 & $<0.020$ & $<0.020$ & $<0.020$ & 0.020 & 0.050 & $<0.020$ \\
\hline B & 0.001 & 0.001 & 0.005 & 0.003 & 0.001 & 0.002 & 0.008 & $<0.002$ \\
\hline $\mathrm{Zn}$ & 0.003 & 0.004 & $>0.050$ & 0.002 & 0.030 & 0.005 & 0.002 & 0.003 \\
\hline $\mathrm{La}$ & $<0.001$ & $<0.001$ & $<0.001$ & $<0.001$ & $<0.001$ & $<0.001$ & $<0.001$ & $<0.001$ \\
\hline $\mathrm{Fe}$ & 97.700 & 98.100 & 98.000 & 97.500 & 98.300 & 98.200 & 97.800 & 97.500 \\
\hline
\end{tabular}

Major elements are given in bold

were compared with standards and are presented in Figs. 5 and 6, respectively. The yield and ultimate tensile strengths varied from 313.31 to $630.12 \mathrm{MPa}$ and 456.82 to $748.80 \mathrm{MPa}$ for the various steel bars of different diameters. Figure 7 shows the percentage elongation of all the reinforcing steel bars of different diameters. The percentage elongation varied from 12 to $31.33 \%$ for the steel bars. The hardness values of all the reinforcing steel bars of different diameters from various steel bars are presented in Fig. 8. The hardness values varied from 11.59 to 18.89 HRC for all the steel bars from different plants.

\section{Effects of Elemental Composition on the Properties}

The carbon contents of the 16,12 and $10 \mathrm{~mm}$ steel bars in this study indicate that they are either low- or medium- carbon steel according to the classification of Roberts and Reza [17]. Compared to various standards, the samples from different plants did not have consistent carbon content as shown in Figs. 2, 3 and 4. This variation in carbon contents of samples from the same steel plants revealed the detrimental effects of using scraps for the production of steel products though there might have been measures taken to control carbon content. Carbon is one of the major determinants of mechanical properties of steel products; thus, its variation may imply discrepancies in strength and ductility of the steel sample [18]. The sulfur and phosphorus contents which are the major deleterious elements in reinforcing steel bars are generally within the proximity of the recommended standards as shown in Table 4. The various deleterious and residual elements present in $16 \mathrm{~mm}$ reinforcing steel bar in the present study were compared 
Table 3 Elemental composition of $10 \mathrm{~mm}$ reinforcing bar samples

\begin{tabular}{|c|c|c|c|c|c|c|c|c|}
\hline \multirow[b]{2}{*}{ Element (wt.\%) } & \multicolumn{8}{|c|}{ Samples } \\
\hline & $\mathrm{A}_{1} \mathrm{R}_{10}$ & $\mathrm{~B}_{1} \mathrm{R}_{10}$ & $\mathrm{C}_{1} \mathrm{R}_{10}$ & $\mathrm{D}_{1} \mathrm{R}_{10}$ & $\mathrm{E}_{1} \mathrm{R}_{10}$ & $\mathrm{~F}_{1} \mathrm{R}_{10}$ & $\mathrm{G}_{1} \mathrm{R}_{10}$ & $\mathrm{H}_{1} \mathrm{R}_{10}$ \\
\hline $\mathrm{C}$ & 0.190 & 0.250 & 0.310 & 0.250 & 0.350 & 0.300 & 0.230 & 0.420 \\
\hline $\mathrm{Si}$ & 0.050 & 0.130 & 0.260 & 0.330 & 0.070 & 0.200 & 0.160 & 0.220 \\
\hline Mn & 0.910 & 0.670 & 0.900 & 1.510 & 0.470 & 0.570 & 0.610 & 0.700 \\
\hline $\mathrm{P}$ & 0.020 & $\mathbf{0 . 0 3 0}$ & 0.040 & 0.001 & 0.020 & 0.020 & 0.040 & 0.004 \\
\hline S & 0.030 & 0.080 & 0.080 & 0.007 & 0.050 & 0.050 & 0.180 & 0.090 \\
\hline $\mathrm{Cr}$ & 0.020 & 0.180 & 0.200 & 0.040 & 0.160 & 0.180 & 0.250 & 0.310 \\
\hline Mo & 0.005 & 0.020 & 0.020 & 0.007 & 0.010 & 0.020 & 0.030 & 0.030 \\
\hline $\mathrm{Ni}$ & 0.002 & 0.120 & 0.220 & 0.020 & 0.100 & 0.130 & 0.160 & 0.160 \\
\hline $\mathrm{Al}$ & $<0.001$ & $<0.001$ & 0.005 & 0.010 & 0.001 & 0.002 & 0.009 & $<0.001$ \\
\hline Co & 0.003 & 0.010 & 0.020 & 0.005 & 0.010 & 0.010 & 0.020 & 0.010 \\
\hline $\mathrm{Cu}$ & 0.030 & 0.290 & 0.390 & 0.050 & 0.170 & 0.200 & 0.004 & 0.400 \\
\hline $\mathrm{Nb}$ & $<0.004$ & $<0.004$ & $<0.004$ & $<0.004$ & $<0.004$ & $<0.004$ & $<0.004$ & $<0.004$ \\
\hline $\mathrm{Ti}$ & $<0.001$ & $<0.001$ & $<0.001$ & $<0.001$ & $<0.001$ & $<0.001$ & $<0.001$ & $<0.001$ \\
\hline $\mathrm{V}$ & 0.005 & 0.009 & 0.005 & 0.0700 & 0.005 & 0.006 & 0.008 & 0.010 \\
\hline W & $<0.007$ & $<0.007$ & $<0.007$ & $<0.007$ & $<0.007$ & $<0.007$ & $<0.007$ & $<0.007$ \\
\hline $\mathrm{Pb}$ & $<0.002$ & $<0.002$ & $<0.002$ & $<0.002$ & $<0.002$ & $<0.002$ & $<0.002$ & $<0.002$ \\
\hline $\mathrm{Sn}$ & 0.002 & 0.020 & 0.040 & 0.004 & 0.020 & 0.010 & 0.030 & 0.020 \\
\hline $\mathrm{Mg}$ & $<0.001$ & $<0.001$ & $<0.001$ & $<0.001$ & $<0.001$ & $<0.001$ & 0.002 & $<0.001$ \\
\hline As & 0.002 & 0.004 & 0.006 & 0.003 & 0.005 & 0.003 & 0.006 & 0.003 \\
\hline $\mathrm{Bi}$ & 0.004 & $<0.002$ & $<0.002$ & 0.003 & $<0.002$ & 0.002 & 0.002 & 0.003 \\
\hline $\mathrm{Ca}$ & 0.002 & 0.003 & 0.004 & 0.003 & 0.002 & 0.005 & $>0.010$ & 0.003 \\
\hline $\mathrm{Ce}$ & $<0.002$ & $<0.002$ & $<0.002$ & $<0.002$ & $<0.002$ & $<0.002$ & $<0.002$ & $<0.002$ \\
\hline $\mathrm{Sb}$ & 0.004 & 0.006 & 0.010 & 0.005 & 0.007 & 0.005 & 0.010 & 0.007 \\
\hline $\mathrm{Se}$ & $<0.001$ & 0.005 & 0.007 & 0.004 & 0.004 & 0.002 & 0.007 & 0.002 \\
\hline $\mathrm{Te}$ & 0.003 & 0.004 & 0.004 & 0.004 & 0.003 & 0.003 & 0.004 & 0.003 \\
\hline Ta & 0.070 & 0.040 & $<0.020$ & 0.060 & 0.030 & 0.040 & $<0.020$ & 0.030 \\
\hline B & 0.001 & 0.001 & 0.004 & 0.002 & 0.007 & 0.002 & $<0.002$ & 0.002 \\
\hline $\mathrm{Zn}$ & 0.004 & 0.003 & 0.040 & 0.002 & 0.020 & 0.007 & 0.002 & 0.004 \\
\hline $\mathrm{Fe}$ & 98.600 & 98.100 & 97.400 & 97.600 & 98.400 & 98.200 & 97.800 & 97.500 \\
\hline
\end{tabular}

Major elements are given in bold

with the report of previous studies $[19,20]$ and standards and are presented in Table 4. The manganese content of some of the investigated reinforcing steel bars are also lower than the recommended standards. This is as a result of high amount of sulfur present in the samples. Manganese nullifies the negative effect of sulfur in steel if present in the right proportion to form $\mathrm{MnS}$ as against the undesirable $\mathrm{FeS}$ which is a brittle compound that affect the mechanical properties of reinforcing steel bars negatively. The phosphorus contents of the $16 \mathrm{~mm}$ reinforcing steel bars for all the steel plants are lower than the recommended standard (Table 4); thus, the steel samples displayed good ductility properties [21]. Despite all the inconsistency in the phosphorus and sulfur contents of the samples, the yield and tensile strength of the majority of the samples still met the required minimum standard for the samples to be used as reinforcement materials. This may be as a result of the combined effects of other residual elements such as manganese and silicon which are good deoxidizers in steel and therefore improves mechanical properties [4, 22]. The contributory effects of chromium, copper and nickel alongside the carbon content could also account for the strengths that met the various standards [18].

Yield Strength and Ultimate Tensile Strength Correlation with Standards

The stress at which deformation changes from elastic to plastic is the yield point which gives the yield strength [21]. The yield strength of reinforcing steel bars that can be used for structural and construction applications was benchmarked at 415,500 and $420 \mathrm{MPa}$ by ASTM A706 [24], BS4449 [23] and NIS 117 [14], respectively. Reinforcing steel bars from plants A, D, G (16 and $12 \mathrm{~mm})$ and 
Table 4 Carbon and other major residual elements in the $16 \mathrm{~mm}$ reinforcing steel bars compared with previous studies and standards

\begin{tabular}{|c|c|c|c|c|c|c|c|c|c|c|}
\hline Samples & $\mathrm{C}$ & $\mathrm{Mn}$ & $\mathrm{Si}$ & S & $\mathrm{P}$ & $\mathrm{Cr}$ & Mo & $\mathrm{Cu}$ & $\mathrm{Ni}$ & References \\
\hline $\mathrm{A}_{3} \mathrm{R}_{16}$ & 0.200 & 0.850 & 0.240 & 0.060 & 0.030 & 0.200 & 0.020 & 0.220 & 0.130 & PS \\
\hline $\mathrm{B}_{3} \mathrm{R}_{16}$ & 0.220 & 0.660 & 0.100 & 0.060 & 0.020 & 0.320 & 0.020 & 0.480 & 0.210 & PS \\
\hline $\mathrm{C}_{3} \mathrm{R}_{16}$ & 0.190 & 0.360 & 0.120 & 0.050 & 0.030 & 0.320 & 0.020 & 0.380 & 0.150 & PS \\
\hline$D_{3} R_{16}$ & 0.200 & 1.360 & 0.340 & 0.030 & 0.020 & 0.070 & 0.020 & 0.140 & 0.060 & PS \\
\hline$E_{3} R_{16}$ & 0.230 & 0.500 & 0.150 & 0.060 & 0.010 & 0.110 & 0.010 & 0.200 & 0.090 & PS \\
\hline $\mathrm{F}_{3} \mathrm{R}_{16}$ & 0.340 & 0.630 & 0.180 & 0.060 & 0.030 & 0.190 & 0.020 & 0.330 & 0.160 & PS \\
\hline $\mathrm{G}_{3} \mathrm{R}_{16}$ & 0.210 & 0.580 & 0.140 & 0.060 & 0.020 & 0.270 & 0.030 & 0.310 & 0.140 & PS \\
\hline $\mathrm{H}_{3} \mathrm{R}_{16}$ & 0.350 & 0.760 & 0.240 & 0.070 & 0.030 & 0.260 & 0.030 & 0.330 & 0.140 & PS \\
\hline PSM & 0.112 & 0.580 & 0.149 & 0.060 & 0.071 & 0.186 & 0.009 & 0.256 & 0.118 & [19] \\
\hline IFSM & 0.277 & 0.720 & 0.319 & 0.057 & 0.069 & 0.138 & 0.005 & 0.285 & 0.115 & [19] \\
\hline PHSM & 0.194 & 0.610 & 0.245 & 0.049 & 0.043 & 0.264 & 0.013 & 0.245 & 0.104 & [19] \\
\hline A16 & 0.329 & 0.555 & 0.176 & 0.036 & 0.042 & 0.164 & 0.0001 & 0.261 & 0.112 & [20] \\
\hline B16 & 0.169 & 0.579 & 0.228 & 0.047 & 0.056 & 0.204 & 0.0001 & 0.292 & 0.085 & [20] \\
\hline NIS 117 & 0.350 & 1.200 & 0.300 & 0.040 & 0.040 & $\ldots$ & $\ldots$ & $\ldots$ & $\ldots$ & [20] \\
\hline BS4449 & 0.250 & 1.000 & 0.400 & 0.050 & 0.050 & $\ldots$ & $\ldots$ & $\ldots$ & $\ldots$ & {$[23]$} \\
\hline ASTM A706 & 0.300 & 1.500 & 0.500 & 0.035 & 0.045 & $\ldots$ & $\ldots$ & $\ldots$ & $\ldots$ & {$[24]$} \\
\hline
\end{tabular}

$P S$ present study

Fig. 2 Carbon content of $16 \mathrm{~mm}$ reinforcing steel bars compared with some standards

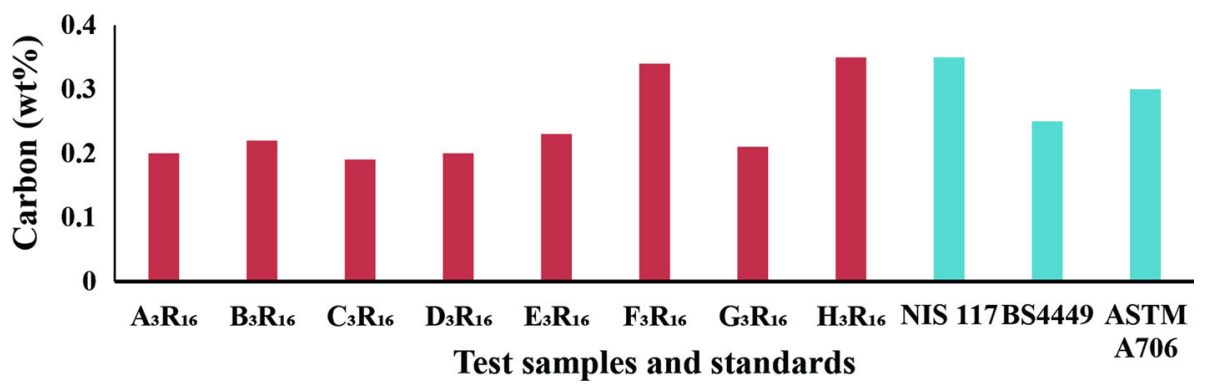

Fig. 3 Carbon content of $12 \mathrm{~mm}$ reinforcing steel bars compared with some standards

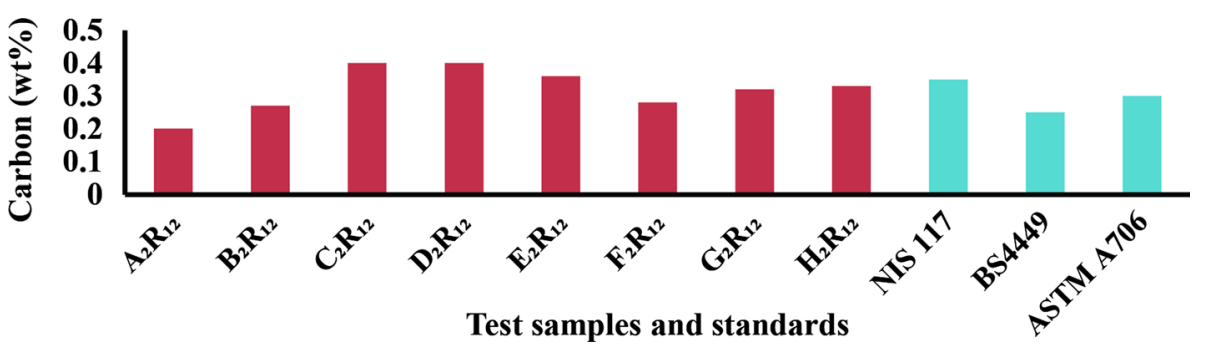

Fig. 4 Carbon content of $10 \mathrm{~mm}$ reinforcing steel bars compared with some standards

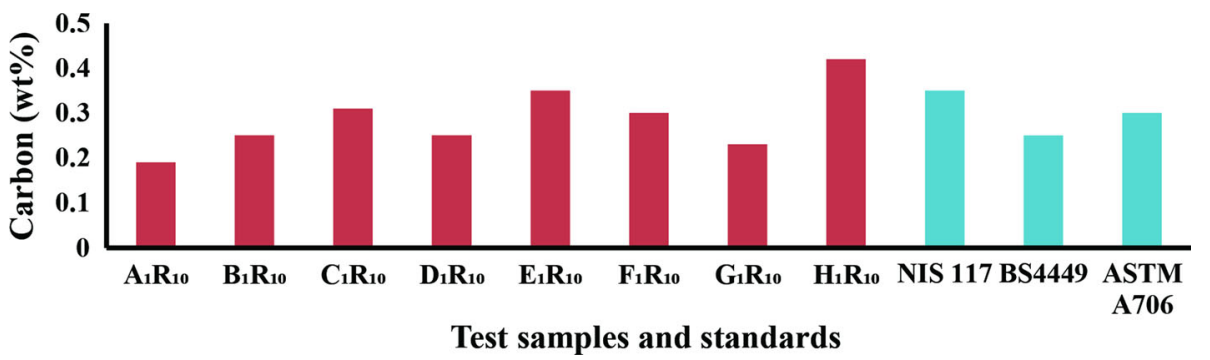

$\mathrm{H}$ (12 and $10 \mathrm{~mm}$ ) have yield strength that surpassed the recommended standards. However, reinforcing steel bars from B have yield strengths that are higher than NIS 117 [14] and ASTM A706 [24] standards but lower than 
BS4449 [23]. Reinforcing steel bars from other plants (varying diameters) have lower yield strength compared to the standards as shown in Fig. 5. The reason for this pattern cannot be ascertain due to the presence of numerous residual elements which is a major disadvantage of using scraps as the key raw material for the production of reinforcing steel bars $[5,7,18]$. The UTS which is the maximum load reinforcing steel bars can withstand before fracture for the reinforcing steel bars varied from each other as shown in Fig. 6. The NIS 117 [14], BS4449 [23] and ASTM A706 [24] standards recommended that the UTS of reinforcing steel bars should surpass 500, 600 and $590 \mathrm{MPa}$, respectively. All the steel bar samples from various plants met this requirement except 16 -mm-diameter sample from steel plant C with UTS of $456.82 \mathrm{MPa}$, which is below the required standards. It is generally observed that there are a lot of differences in the mechanical properties and chemical compositions of steel bar samples from the same plant. Reinforcing steel bars from steel plants C and D have similar percentage elongation at all the diameters as against various variations from samples from other steel plants. It implies that they possess similar ductile nature. The percentage elongation of the steel bars in the present study competes favorably with previous studies as shown in Table 5. It can be observed that they are higher than what was reported by Adeleke and Odusote [7] for reinforcing steel bars that does not meet required standards. Insufficient ductility of reinforcing steel bars has direct influence on the ductility of

Table 5 Mechanical properties of $16 \mathrm{~mm}$ reinforcing steel bar samples compared with previous studies

\begin{tabular}{lccccl}
\hline Specimen & $\begin{array}{c}\text { YS } \\
(\mathrm{MPa})\end{array}$ & $\begin{array}{c}\text { UTS } \\
(\mathrm{MPa})\end{array}$ & $\begin{array}{c}\% \\
\text { Elongation }\end{array}$ & $\begin{array}{c}\text { Hardness } \\
(\text { HRC })\end{array}$ & References \\
\hline $\mathrm{A}_{3} \mathrm{R}_{16}$ & 581 & 699 & 17.0 & 17.6 & Present study \\
$\mathrm{B}_{3} \mathrm{R}_{16}$ & 502 & 635 & 17.7 & 16.1 & Present study \\
$\mathrm{C}_{3} \mathrm{R}_{16}$ & 313 & 457 & 26.3 & 11.6 & Present study \\
$\mathrm{D}_{3} \mathrm{R}_{16}$ & 550 & 703 & 20.0 & 17.5 & Present study \\
$\mathrm{E}_{3} \mathrm{R}_{16}$ & 347 & 511 & 31.3 & 13.1 & Present study \\
$\mathrm{F}_{3} \mathrm{R}_{16}$ & 412 & 607 & 23.7 & 15.5 & Present study \\
$\mathrm{G}_{3} \mathrm{R}_{16}$ & 574 & 657 & 16.7 & 16.7 & Present study \\
$\mathrm{H}_{3} \mathrm{R}_{16}$ & 412 & 673 & 20.0 & 16.9 & Present study \\
EC & 460 & 597 & 9.0 & 21.2 & {$[7]$} \\
IC & 486 & 586 & 11.7 & 20.2 & {$[7]$} \\
SC & 551 & 626 & 9.1 & 19.6 & {$[7]$} \\
SF & 400 & 693 & 18.0 & 47.9 & {$[5]$} \\
US & 450 & 652 & 28.0 & 44.3 & {$[5]$} \\
NS & 400 & 611 & 28.0 & 47.3 & {$[5]$} \\
AS & 325 & 660 & 25.0 & 45.5 & {$[5]$} \\
Type L & 429 & 679 & 29.2 & $\ldots$ & {$[26]$} \\
Type F & 415 & 610 & 27.9 & $\ldots$ & {$[26]$} \\
\hline
\end{tabular}

reinforcement concrete structural members [25]. Figure 7 shows that all the reinforcing steel bars have sufficient ductility to resist unfavorable distribution of plastic deformations and premature tensile fracture and buckling under use.

\section{Hardness and Percentage Elongation}

Hardness is the resistance of materials to abrasion [21]. Hardness of the $16 \mathrm{~mm}$ reinforcing steel samples from steel plants $\mathrm{C}$ and $\mathrm{E}$ does not meet any of the required ASTM (15.46 HRC) and BS4449 (13.48 HRC) standards as shown in Fig. 8. Conversely, all the $12 \mathrm{~mm}$ steel bars from steel plants A to $\mathrm{H}$ meet the required ASTM and BS4449 standards. However, only the reinforcing steel bars from steel plant $G$ does not meet the required standards among the 10-mm-diameter bars. Table 5 shows the hardness value (HRC) of the steel bars in the present study compared to some results from previous studies $[5,7,26]$. The hardness value of a typical steel bar diameter $(16 \mathrm{~mm})$ is far lower than the results obtained by Alabi and Onyeji [5]; and Adeleke and Odusote [7]. Alabi and Onyeji [5] reported that the high hardness value was due to high carbon content in the studied samples and recommended that reinforcing steel bar must have high hardness value to be effective in construction and structural applications. When the hardness value is lower than recommended standards, the performance in service will be definitely affected. Another notable pattern in the hardness values of the reinforcing steel bars from the same and different steel plants varied from one another. This could also be due to various contributions of the residual and deleterious elements present when scraps are used as major source of raw material for steel production. Apeh [27] also reported that most of the steel bars made from scraps sold in FCT, Abuja market, were mild steel claimed to be high-yield steel even though the chemical properties did not meet required BS 4449 standard. It was also stated that only $19 \%$ of the steel bars analyzed met required percentage elongation. Variations in the chemical, percentage elongation, hardness and tensile strengths of steel bars produced from scraps (ST442 and ST66-2) were also reported by Buliaminu [28]. Meanwhile, investigated steel bars manufactured from billet in Pakistan were reported by Rafi et al. [29]. The chemical composition met required ASTM standard, while it was observed that some did not meet required standard for yield strength. It thus implied that, regardless of the raw materials used for the production of steel bars, there is a possibility of variation in its chemical and mechanical properties. Therefore, based on the findings of this study, it is recommended that reinforcing steel bars produced from scraps and billets should be thoroughly tested before application at various construction sites to ascertain their 
Fig. 5 Yield strength of the reinforcing steel bar samples compared with some standards

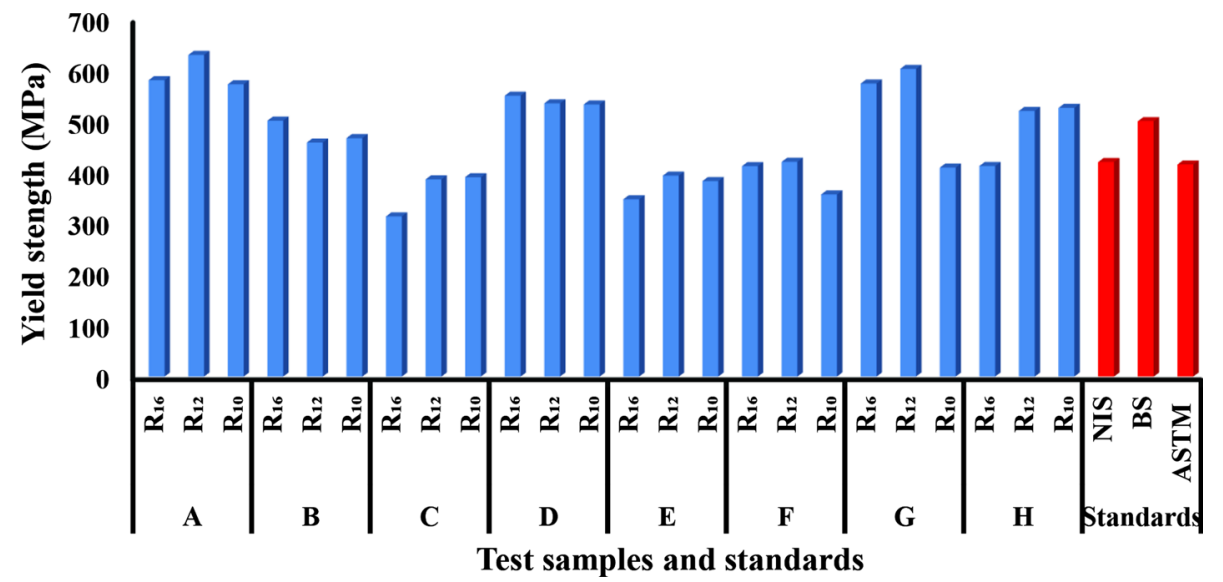

Fig. 6 Ultimate tensile strength (UTS) of the reinforcing steel bar samples compared with some standards

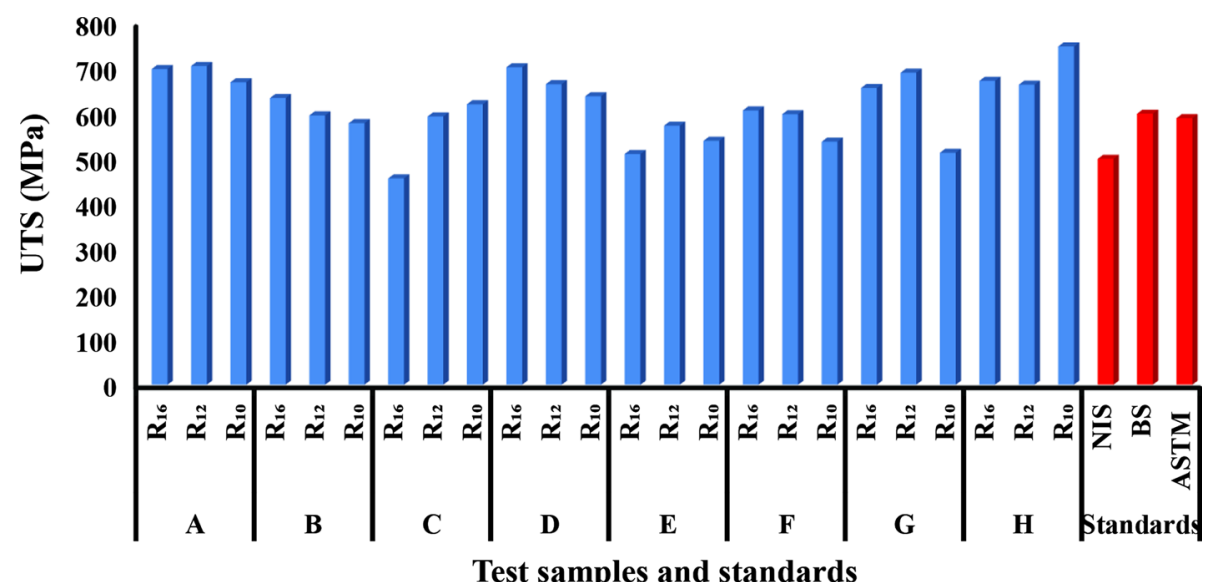

Fig. $7 \%$ elongation of the reinforcing steel bar samples compared with some standards

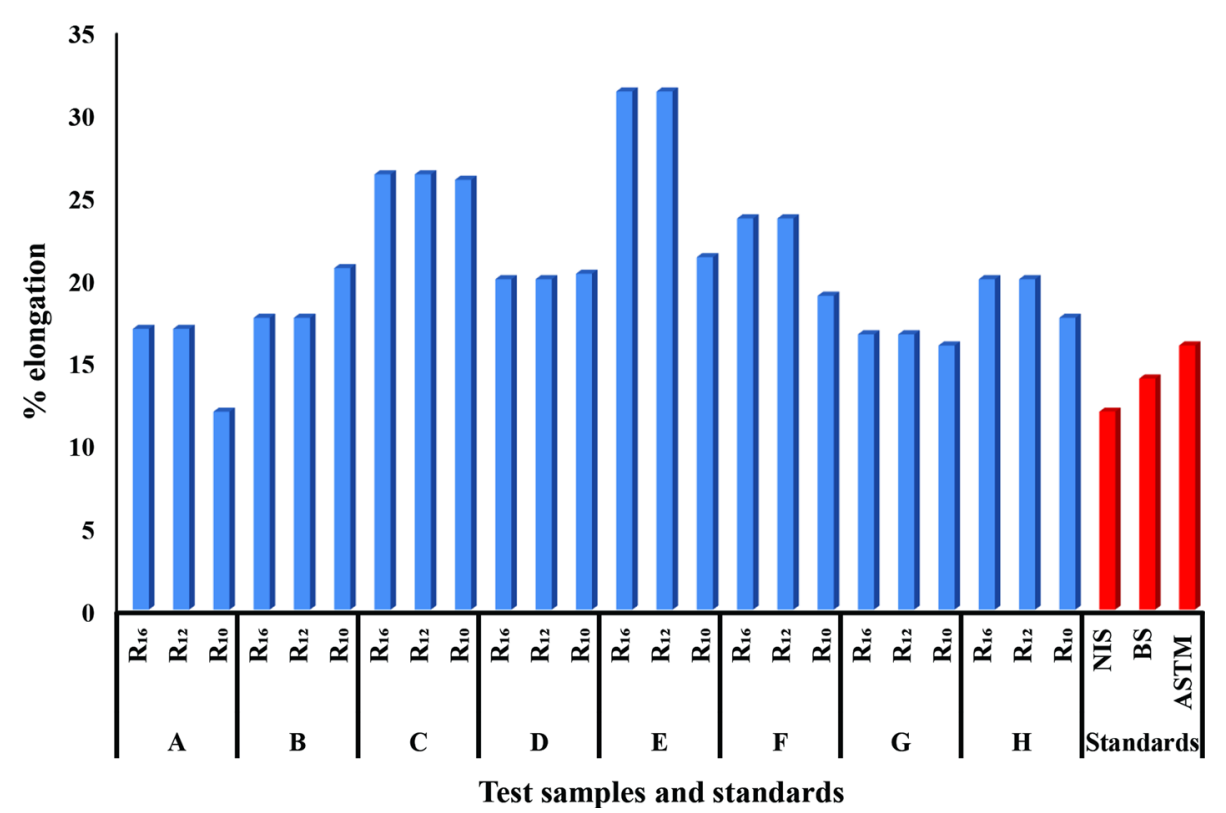

quality in order to avoid further loss of lives. Researchers can further look into the means of reduction of various residual elements that impacts negative properties of the steel bars produced from scraps. 
Fig. 8 Hardness value of the reinforcing steel bar samples compared with some standards

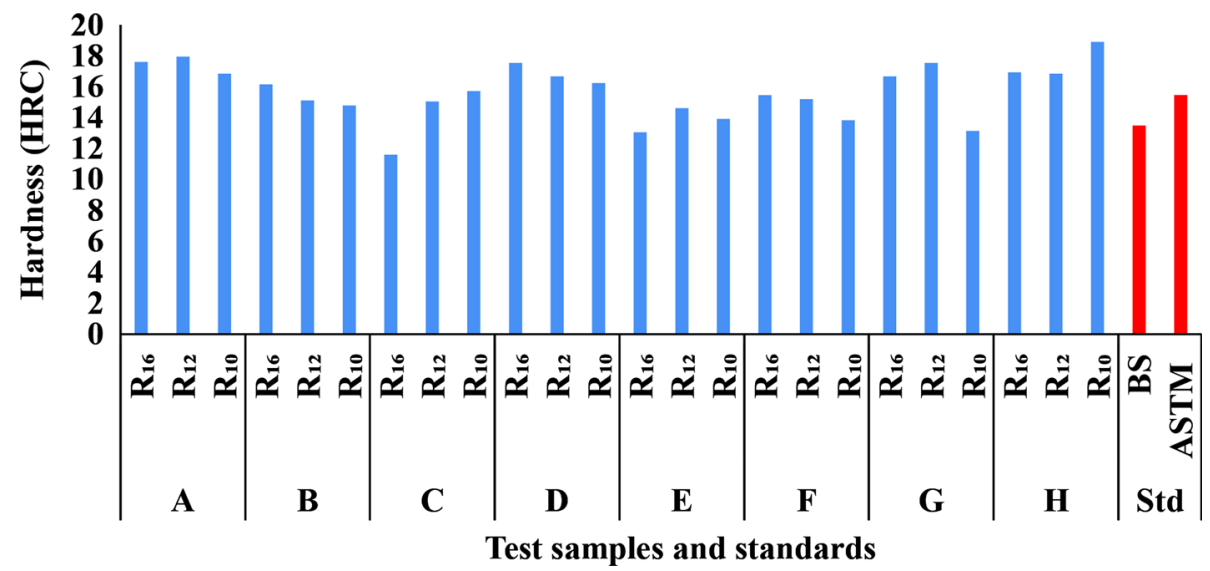

\section{Conclusions}

The chemical and mechanical properties of reinforcing steel bars from local steel plants have been investigated. The chemical analyses showed that there are thirty-one (31) major, residual and deleterious elements present in the reinforcing steel bars. Variations in carbon contents as well as manganese, silicon, sulfur and phosphorus had varying impacts on the mechanical properties of the reinforcing bars. The outcome of the investigation also revealed that some of the samples have yield strength that surpasses the recommended standard specifications and can be useful for structural/construction purposes. In conclusion, most of the steel bars met all the standards in terms of yield strength, ultimate tensile strength ductility and hardness values and can thus be used for structural applications.

\section{References}

1. M. Jibrin, Characterization of reinforcing steel bars in the Nigeria Construction Industry, Ph.D. thesis, Department of Civil Engineering, Ahmadu Bello University, Zaria, Kaduna State (2012)

2. C. Arum, Verification of properties of concrete reinforcement bars: Nigeria as a case study. Indoor Built Environ. 17(4), 370376 (2008)

3. C.B. Prabir, P. Shylamoni, A.D. Roshan, Characterization of steel reinforcement for RC structure: an overview and related issues. Indian Concr. J 78, 19-30 (2004)

4. J.K. Odusote, A.A. Adeleke, Analysis of properties of reinforcing steel bars: case study of collapsed building in Lagos, Nigeria. J. Appl. Mech. Mater. 204-208, 3052-3056 (2012)

5. A.G.F. Alabi, L.I. Onyeji, Analysis and comparative assessment of locally produced reinforcing steel bars for structural purposes. USEP: J. Res. Civ. Eng. 7, 49-60 (2010)

6. A.G.F. Alabi, R. Yahya, Comparative assessment of some commercial steel bars with standard. J. Res. Inf. Civ. Eng. 9, 73-83 (2012)

7. A.A. Adeleke, J.K. Odusote, Evaluation of mechanical properties of reinforcing steel bars from collapsed building sites. J. Fail. Anal. Prev. (2013). https://doi.org/10.1007/s11668-013-9739-5
8. J.O. Osarewenmwinda, E.C. Amuchi, Quality assessment of commercially available reinforced steel rods in Nigeria market. J. Emerg. Trends Eng. Appl. Sci. 4(4), 562-565 (2013)

9. A.G.F. Alabi, O. Akintunde, J.K. Odusote, A.A. Adeleke, Assessment of suitability of Nigerian made steel bars for structural application. J. Ass. Prof. Eng. Trinidad Tobago 44(2), 17-23 (2016)

10. A.A. Adeleke, J.K. Odusote, P.P. Ikubanni, O.A. Lasode, O.O. Agboola, A. Ammasi, K.R. Ajao, Dataset on the evaluation of chemical and mechanical properties of steel rods from local steel plants and collapsed building sites. Data Brief 21, 1552-1557 (2018)

11. P.P. Ikubanni, A.A. Adediran, A.A. Adeleke, K.R. Ajao, O.O. Agboola, Mechanical properties improvement evaluation of medium carbon steel quenched in different media. Int. J. Eng. Res. Afr. 32, 1-10 (2017)

12. A.A. Adeleke, P.P. Ikubanni, A.A. Adediran, O.O. Agboola, T.S. Olabamiji, O.J. Ogunsola, C. Ibeawuchi, Tensile strength and micro-structural behaviour of medium carbon steel quenched in some selected media. Int. J. Civ. Eng. Tech. 9(10), 2148-2156 (2018)

13. P.P. Ikubanni, O.O. Agboola, A.A. Adediran, A.A. Adeleke, B.T. Ogunsemi, T.S. Olabamiji, D.C. Uguru-Okorie, C.O. Osueke, Experimental Data on mechanical properties evaluation of medium carbon steel quenched in different waste media. Data Brief 20, 1224-1228 (2018)

14. Specification for steel bars for reinforcement of concrete. Nigeria industrial standard NIS 117-1992, Standard Organization of Nigeria (SON), Abuja, Nigeria

15. Nigerian Industrial Standard (NIS), Specification for Steel Bars for the Reinforcement of Concrete (Standard Organization of Nigeria (SON), Abuja, 2004)

16. Standard Table Correlating Tensile Strength and Hardness of Steel, (n.d.). (2017) Retrieved May 13, 2018, from http://www. engineershandbook.com/Table/hardness.htm

17. E. Roberts, A. Reza, Physical Metallurgy Principles, 3rd edn. (PWS-KENT Publishing, Boston, 1992)

18. K. Serope, R. Schimid, Manufacturing Engineering and Technology, 2nd edn. (Person education, South Asia Pte LTD, Singapore, 2006)

19. B. Sambo, E. David, A. Samson, B. Olatunde, Challenges of producing quality construction steel bars in West Africa: case study of Nigeria Steel Industry. J. Miner. Mater. Charact. Eng. 8, 283-292 (2009)

20. K. Charles, M. Adom-Asamoah, Strength and ductility characteristics of reinforcing steel bars milled from scraps metals. Mater. Des. J. 23, 537-545 (2002) 
21. R. Higgins, Engineering Metallurgy, Part 1: Applied Physical Metallurgy, 6th edn. (England: Edward Arnold Bodmin, Cornwall, Ch. 7 1993), pp. 11-18

22. M. Kutz, Role of Alloying Elements in Steel. Hand Book of Materials Selections (Kutz Myer Associates, Wiley, New York, 2002)

23. British Standard (BS4449), (1997) Available from Jentayu: http:// www.jentayuventure.com. Accessed 12 Mar 2018

24. American Standard (ASTM), A 706, Metals, Test Methods and Analytical Procedures, Metal-Mechanical Testing; Elevated and low-temperature Tests: Metallographic (1990). https://www.astm. org/Standards/A706.htm. Accessed 12 Mar 2018

25. H. Bachmann, T. Wenk, Ungeniigende duktilitat beim bewehrungsstahl (Insufficient Ductility of Reinforcing Steel). Sch. Ing. Arch. J. 29(7), 544-551 (1998)
26. R. Higgins, Engineering Metallurgy (Viva Books Private Limited, New Delhi, 2004)

27. A.J. Apeh, Assessment of mechanical properties of reinforcing steel used in construction works at F.C.T., Abuja. Int. J. Eng. Res. Tech. 2(6), 2346-2358 (2013)

28. K. Buliaminu, Tensile and chemical analyses of selected steel bars produced in Nigeria. AU J. Tech. 13(1), 29-33 (2009)

29. M.M. Rafi, S. Lodi, A. Nizam, Chemical and mechanical properties of steel rebars manufactured in Pakistan and design implications. J. Mater. Civ. Eng. 26(2), 338-348 (2014)

Publisher's Note Springer Nature remains neutral with regard to jurisdictional claims in published maps and institutional affiliations. 